\title{
INTERNAL AUDIT EFFICIENCY EVALUATION PRINCIPLES
}

\author{
Olga Savčuk \\ Vilnius Gediminas Technical University, Saulètekio al. 11, 10223 Vilnius, Lithuania, \\ e-mail: olga.savcuk@lt.ey.com \\ Received 15 December 2006; accepted 20 January 2007
}

\begin{abstract}
Current business environment has experienced rapid and revolutionary change with far reaching consequences for companies worldwide. Management responses to fierce global competition include improved quality and risk management initiatives, reengineered structures and processes and greater accountability to ensure more timely, reliable and relevant information for decision-making and to secure confidence and trust of the investors. Over the last few years the importance to the strong corporate governance of managing risk has been increasingly acknowledged. Companies are under pressure to identify all the business risks they face: social, ethical and environmental as well as financial and operational, and to explain how they manage them to an acceptable level. Therefore in order to reach its objectives each company has to develop and implement an approach to assessing and managing the uncertainties and opportunities it faces in the pursuit of its business strategy, with the intention of maximizing shareholder value and performance, i.e. meeting the determined objectives. Shareholders are extremely demanding with respect to the activities of the management and want an independent and objective assessment of the risk management and governance system the management is responsible for.

In this radically changed business environment the internal auditing gained an important role within companies. Over the past sixty years internal audit developed from control function responsible for inspection of accounting and financial data to a strategic partner for the shareholders and the management of the company in improving governance processes. In current environment the management of the company more and more rely on the internal audit to evaluate whether controls are sufficient to manage risks and uncertainties. This developing role of the internal auditing is also reflected in its current definition, i.e. internal auditing is an independent, objective assurance and consulting activity designed to add value and improve a company's operations. It helps an organization accomplish its objectives by bringing a systematic, disciplined approach to evaluate and improve the effectiveness of risk management, control and governance processes. Only efficient internal audit can perform its tasks properly. Internal audit efficiency depends on its subordination level, which must be appropriate for internal audit to be independent and objective, on the professional qualification and practical experience of internal audit staff, on the internal audit strategy, activities and value added to the company and on the ability to improve itself.

The article analyses efficient internal audit establishment and support issues and internal audit efficiency estimation principles. Taking into account the scope of organization's direction and control, internal audit takes on important roles, integrating several other governance and control aspects into organizational governance and stands out as the most important, single mechanism for ensuring adequate and effective governance of the organization. The article provides criteria to assess efficiency of internal audit which could be applied when implementing internal audit function or improving the existing one.
\end{abstract}

Keywords: internal auditing, risk management, internal audit efficiency, subordination.

\section{Introduction}

In the current business environment internal auditors in their activities face many challenges and opportunities, including increasingly complex and pervasive technology, a need for new skills, rapidly changing organizational structures, demand for an expanding scope of services and increasing competition and globalization. Internal auditors are developing new strategies to meet these challenges and are becoming more proactive, providing a broadened variety of services and otherwise changing the internal audit model. Over several past years there has been a significant pressure for improved governance of the organizations, which was caused by accounting scandals, corporate disasters and their significance, changes in corporate share ownership patterns and in the legal environment. The main reasons that caused requirement to improve corporate governance were accounting scandals and corporate disasters (Enron (US), WorldCom (US), Sumitomo (Japan) [1]), which were significant in scope, continuing to occur with an enormous regularity (e.g., financial frauds, bankruptcies, manipulations with earnings, accounting principles, etc.), and these disasters often were accompanied by questioning where members of the board, auditors, regulators were.

Among a lot of negative consequences of poor governance processes are bankruptcies, frauds, earnings restatements, quickly diminishing in value stocks, loss 
of credibility, loss of business partners, loss of customers, loss of careers and many other negative impacts on the activities of organizations. It is obvious that none of the organizations can afford the cost of governance failures. It is obvious that in current days and circumstances it is not sufficient to establish a formal corporate governance process within an organization. It is extremely important to ensure the efficiency of this process. Internal audit plays a very important role in the organizational governance, therefore it is required from the internal auditor not only to perform ordinary assurance activities, which were sufficient some time ago, but also to become a strategic partner of the organization and add value to its activities improving governance processes and ensuring their efficiency. Therefore internal audit function efficiency question becomes increasingly important.

\section{Evolution of internal audit}

In order to determine internal audit efficiency evaluation principles it is important to analyze the concept of internal audit and its evolution. The first description of internal auditing activities reflecting responsibilities of the internal auditor and the requirements to this profession was introduced by Victor Z. Brink and Lawrence B. Sawyer in the year 1947 in the Statement of Responsibilities of the Internal Auditors, issued by the Institute of Internal Auditors (hereinafter - IIA) [2]. In those days the internal auditing primarily dealt with the accounting and financial matters. In the year 1957, the Statement of Responsibilities of Internal Auditing [3] had been considerably broadened to include numerous services to management, i.e. reviewing, appraising the soundness, adequacy, application of accounting, financial, and operating controls; ascertaining the extent of compliance with established policies, plans, and procedures; ascertaining the extent to which company assets are accounted for, and safeguarded from, losses of all kinds; ascertaining the reliability of accounting and other data developed within the organization; appraising the quality of performance in carrying out assigned responsibilities. However it is clearly seen that still the broadened list of the internal auditing functions included only assurance activities on the adequacy of the accounting, financial, operating controls, compliance with the procedures, safeguard of the assets, reliability of the accounting and assignment of the responsibilities within the organization.

In the year 1978 the IIA formally approved the Standards for the Professional Practice of Internal Auditing, which included the following definition of the internal auditing [4]: "Internal auditing is an independent ap- praisal activity established within an organization as a service to the organization. It is a control which functions by examining and evaluating the adequacy and effectiveness of other controls. The objective of internal auditing is to assist members of the organization in the effective discharge of their responsibilities. To this end, internal auditing furnishes them with analyses, appraisals, recommendations, counsel, and information concerning the activities reviewed. The audit objective includes promoting effective control at reasonable cost." The definitions clearly indicated that internal auditing functions were broadened from pure financial reporting assurance to the internal control system and operational assurance, however still the activities were limited to the assurance only, as the business environment of those days was satisfied with these activities.

It was well-understood in the early 1990s that internal auditors, depending on their particular organization's needs and preferences, worked in several areas: compliance audits, audits of transaction cycles, investigating fraud and other irregularities, evaluating operational efficiency, analysis, measurement and reporting of operational and organization-wide risks, and other assurance and consulting activities, despite the fact that formally the definition of the internal audit included only assurance activities. In performing many of these activities, internal auditors made their approach risk-based and controls-focused.

In the year 2002 the new definition of internal auditing was designed to accommodate the profession's expanding role and responsibilities [5]: "Internal auditing is an independent, objective assurance and consulting activity designed to add value and improve an organization's operations. It helps an organization accomplish its objectives by bringing a systematic, disciplined approach to evaluate and improve the effectiveness of risk management, control, and governance processes."

For the first time and till now the internal audit was started to be understood as both assurance and consulting activity required adding value to the organization. Therefore new definition of the internal audit is proactive, customer-focused, concerned with risk management, control, governance. It must be objective and required from internal audit more input to improving organizational operations, concentrating on the whole organization and ensuring its objectives are being met.

So the evolution of the internal auditing activities (Fig. 1) clearly emphasized that it is not enough for the internal auditor to perform pure assurance functions - in order to survive and be a part of the organization internal auditing must add value to the activities 


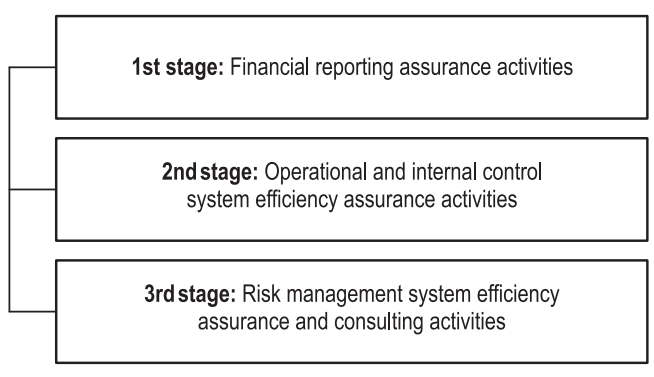

Fig. 1. Internal audit activities - evolution [6]

of the audited organization, however at the same time securing independence and objectivity. Increasing importance of internal audit and evolution of its activities raised the issue of efficiency as it is obvious that only efficient internal audit can be a valuable function able to perform its tasks.

\section{Internal audit implementation principles}

Internal audit being a constituent part of corporate governance can add value to the company only if efficiency is assured. As internal audit is performed in different cultural and legal environment, which differ by objectives, size, complexity and structure, it is necessary to ensure internal audit all over the world implemented in accordance with certain common basic principles. Such principles called Standards on Internal Auditing are being created and announced by the Institute of Internal Auditors. They include basic requirements for implementation of internal audit, however only standards do not give comprehensive suggestions how efficient internal audit must be implemented.

It is worth to notice that there are no legal acts which determine obligation to apply these standards in practice, however all over the world internal audit specialists acknowledge these standards and insistently require to follow them. Table 1 provides the main requirements of the Standards on Internal Auditing.

Table 1. Standards on Internal Auditing - summary [5]

\begin{tabular}{|l|l|}
\hline \multicolumn{1}{|c|}{ Standard } & \multicolumn{1}{c|}{ Comments } \\
\hline $\begin{array}{l}\text { 1000/Purpose, } \\
\text { Authority, and } \\
\text { Responsibility }\end{array}$ & $\begin{array}{l}\text { Charter approved by the board is } \\
\text { obligatory, charter must include } \\
\text { the purpose, authority, and } \\
\text { responsibility of the internal audit }\end{array}$ \\
\hline $\begin{array}{l}\text { 1100/Independence } \\
\text { and Objectivity }\end{array}$ & $\begin{array}{l}\text { The internal audit activity should } \\
\text { be independent and subordinated } \\
\text { to the appropriate management } \\
\text { level to ensure independence and } \\
\text { objectivity }\end{array}$ \\
\hline
\end{tabular}

End of Table 1

\begin{tabular}{|c|c|}
\hline Standard & Comments \\
\hline $\begin{array}{l}\text { 1200/Proficiency } \\
\text { and Due } \\
\text { Professional Care }\end{array}$ & $\begin{array}{l}\text { Engagements should be performed } \\
\text { with proficiency and due } \\
\text { professional care, continuous } \\
\text { professional development must be } \\
\text { present to ensure efficiency }\end{array}$ \\
\hline $\begin{array}{l}\text { 1300/Quality } \\
\text { Assurance and } \\
\text { Improvement } \\
\text { Program }\end{array}$ & $\begin{array}{l}\text { It is obligatory to develop and } \\
\text { maintain a quality assurance and } \\
\text { improvement program that covers } \\
\text { all aspects of the internal audit } \\
\text { activity and continuously monitors } \\
\text { its effectiveness. This program } \\
\text { includes periodic internal and } \\
\text { external quality assessments and } \\
\text { ongoing internal monitoring. The } \\
\text { Standards do not provide efficiency } \\
\text { estimation factors }\end{array}$ \\
\hline $\begin{array}{l}\text { 2000/Managing } \\
\text { the Internal Audit } \\
\text { Activity }\end{array}$ & $\begin{array}{l}\text { The chief audit executive should } \\
\text { effectively manage the internal } \\
\text { audit activity to ensure it adds } \\
\text { value to the organization }\end{array}$ \\
\hline $\begin{array}{l}2100 / \text { Nature of } \\
\text { Work }\end{array}$ & $\begin{array}{l}\text { The internal audit should evaluate } \\
\text { and contribute to the improvement } \\
\text { of risk management, control, and } \\
\text { governance processes }\end{array}$ \\
\hline $\begin{array}{l}\text { 2200/Engagement } \\
\text { Planning }\end{array}$ & $\begin{array}{l}\text { Internal auditors should develop } \\
\text { and record a plan for each } \\
\text { engagement, including the scope, } \\
\text { objectives, timing and resource } \\
\text { allocations }\end{array}$ \\
\hline $\begin{array}{l}\text { 2300/Performing } \\
\text { the Engagement }\end{array}$ & $\begin{array}{l}\text { Internal auditors should identify, } \\
\text { analyze, evaluate, and record } \\
\text { sufficient information to achieve } \\
\text { the engagement's objectives }\end{array}$ \\
\hline $\begin{array}{l}2400 / \\
\text { Communicating } \\
\text { Results }\end{array}$ & $\begin{array}{l}\text { Internal auditors should } \\
\text { communicate the engagement } \\
\text { results }\end{array}$ \\
\hline $\begin{array}{l}\text { 2500/Monitoring } \\
\text { Progress }\end{array}$ & $\begin{array}{l}\text { It is obligatory to establish and } \\
\text { maintain a system to monitor } \\
\text { the disposition of results } \\
\text { communicated to management }\end{array}$ \\
\hline
\end{tabular}

Taking into account analysis of the main standards on internal auditing, four main areas of importance for implementation of internal auditing must be followed (Fig. 2): 


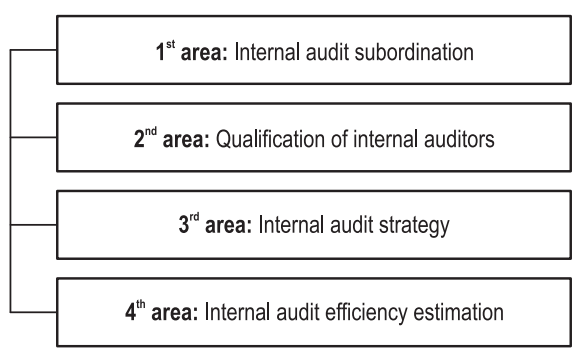

Fig. 2. Areas of internal audit implementation

\section{$1^{\text {st }}$ area: Internal audit subordination}

Standards on Internal Auditing require that internal audit function should be subordinated to the audit committee, which is responsible for:

- Monitoring of internal control and risk management system, ensuring that risks are properly identified, managed and reported, ensuring risk management process is constant and comprehensive;

- Ensuring efficiency of internal audit (if established), recommend on the employment or dismissal of internal audit function head and on the budget of internal audit function, review of internal audit plans, reports and recommendations;

- Ensuring that the management responds and implements recommendations provided by internal audit.

It is noticeable that not all the companies have or will have independent audit committees representing shareholders" interests. Analysis of the governance and ownership structure in 300 biggest Lithuanian companies, (by the year 2006 turnover from AMADEUS database [7]) showed, that none of the companies has an audit committee.

According to the results of the Lithuanian companies ownership structure analysis the following groups of the companies are identified (Fig. 3):

- Shareholder - management, $28 \%$;

- Shareholder - foreign entity (entities), $26 \%$;

- Shareholder - Lithuanian entity (entities), $23 \%$;

- Shareholder - Lithuanian private individual (individuals), $9 \%$;

- Mixed ownership, which do not have one dominant group of shareholders, $6 \%$;

- Shareholder - Lithuanian state, $5 \%$;

- Shareholder - foreign private individual (individuals), $1 \%$;

- Shareholder - foreign investment fund (funds), $1 \%$;

- Shareholder - Lithuanian investment fund (funds), $1 \%$.

The results of the research indicate that companies owned by the management are dominated in Lithuania, i.e. $28 \%$ of the Lithuanian companies are owned by

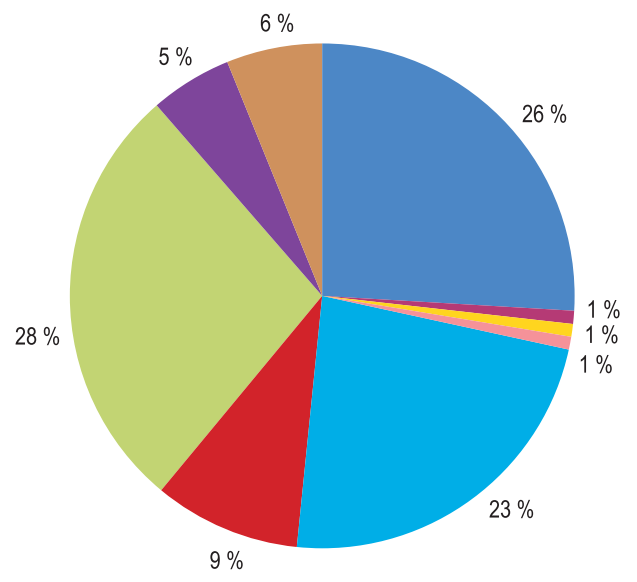
foreign entity (entities)
foreign private individual (individuals)
foreign investment funds
Lithuanian private individual (individuals) management
Lithuanian investment funds
Lithuanian state
Mixed ownership
Lithuanian entity (entities)

Fig. 3. Ownership structure in Lithuanian companies

the same persons who manage the company. The other two significant groups of the companies are owned by Lithuanian entity (entities) or foreign entity (entities), i.e. there is a separation of ownership and management. Taking into account theoretical internal audit subordination requirements and the results of the practical research further Fig. 4 provides recommendations for internal audit subordination depending on the ownership type of the company. The companies are grouped based on the recommendations for internal audit subordination level.

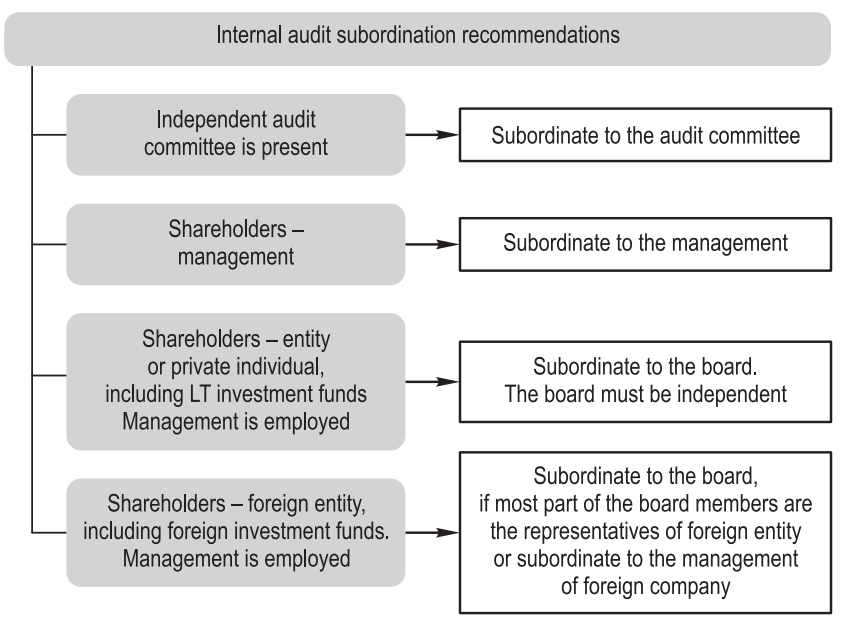

Fig. 4. Internal audit subordination recommendations

1 group: independent audit committee present: in case the company has independent audit committee, without reference to the ownership structure, internal audit to be subordinated to audit committee. 
2 group: shareholders - management: in case the company is owned by its management, there is no conflict of interest, which is present when there is a separation of ownership and management. In these companies the management is interested in business safety and value increase, therefore internal audit can be subordinated to the management and be useful as a function, able to assist the management in assessing their activities, risk management and recommend improvement steps.

3 group: shareholders - entity or private individual, including LT investment funds. Management is employed: in these companies internal audit must be subordinated to the board on condition that part of its members are independent, i.e. are not related to the management of the company. Such subordination will ensure independence of internal audit, as there is a separation of ownership and management in these companies, which causes conflict of interest. Therefore shareholders will have an independent assurance that their investments are safe and company is efficiently managed.

4 group: shareholders - foreign entity, including foreign investment funds. Management is employed: in these companies internal audit must be subordinated to the independent board as it is indicated in the group 3, however the most part of the board members must be representatives of the foreign company. Also internal audit might be subordinated to the management of the foreign company, who are inspected by the internal auditors of this entity.

Taking into account these recommendations and results of the research, it is obvious, that in practice internal audit functionally might be subordinated not only to the audit committee, but also to the other management levels and selection of such a level is impacted by the ownership structure in the company.

\section{$2^{\text {nd }}$ area: Qualification of internal auditors}

The other main internal audit efficiency assurance area is qualification and professional knowledge of internal audit function staff. There is no scientific research or legal acts determining strict requirements for the qualification of internal auditor. However certain practical research $[8,12]$ and certification requirements determine qualification requirements and are acknowledged all over the world. The main and most important qualification certification is Certified Internal Auditor (CIA), which must be compulsory for the internal auditor to be at the highest level of professionalism. This certification assures internal auditor possesses adequate theoretical and practical knowledge, also continuous professional improvement is required to retain this certification. Other certificates as ACCA or local CPA also are appropriate, however CIA is the main aim for all the internal auditors. Based on the CIA requirements and practical research performed in various countries by [8] analyzing personal characteristics and professional qualities of practicing internal auditors the following qualification requirements for internal auditors can be determined (Fig. 5):

\begin{tabular}{|c|}
\hline Support of qualification (professional certification). CIA is obligatory \\
\hline $\begin{array}{c}\text { Practical experiences and personal characteristics (professionalism, } \\
\text { analytical skills, integrity, objectivity, communication skills, } \\
\text { decision making capabilities, responsibility) }\end{array}$ \\
\hline Continuous professional improvement \\
\hline
\end{tabular}

Fig. 5. Qualification requirements for internal auditor

These requirements are taken into account when creating internal audit efficiency score.

\section{$3^{\text {rd }}$ area: Internal audit strategy}

There is a number of ways the organization can manage risks to bring them an acceptable level. The organization can avoid the risks, however this may mean giving up significant opportunities. The organization can transfer risks (e.g. insurance), the organization can tolerate risks, without planning any contingencies. This does not mean that no-one will address this risk, but the means for its management will be created and implemented only when the organization faces the risk actually. Also it is possible to tolerate risk and plan contingencies, i.e. create management means if the risk becomes reality. Also it is possible to introduce some processes to reduce the consequence or likelihood of a risk. These processes are usually referred to as 'controls' and include everything from having a clear strategy to installing an alarm system. However certain framework must be in place to decide which particular way of the risk management has to be selected and implemented. Without such a framework it is not possible to decide whether the risk should be avoided or whether it should be managed, or its consequences or likelihood should be reduced. Supporting the importance of risk management for the organization in order to determine what particular role in it must be attributed to the internal audit it is necessary to identify what steps this process must include and what particular activities must be estimated by the internal auditor in order to ensure its efficiency. 
It is obvious that there is no one single and universal risk management framework to be adopted in all cases, however summarizing analysis of risk management methodologies [9], in our opinion, the below steps are in common and as it is depicted in Fig. 6, must be present in each organization when implementing risk management process, which must be inspected and evaluated by the internal auditor:

- Analysis of the internal environment and determining risk management context - the internal environment encompasses the tone of an organization, and sets the basis for how risk is viewed and addressed by an entity's people, including risk management philosophy and risk appetite, integrity and ethical values, and the environment in which they operate. It is necessary to obtain a comprehensive understanding of the organization, focusing on overall strategy, vision, mission, objective setting, risk appetite, risk tolerances, and the interrelationships therein. It is critical to understand what the company does, how it buys, from whom it buys, how it sells, where it manufactures, etc.

- Objective Setting - Objectives must exist before management can identify potential events affecting their achievement. Enterprise risk management ensures that management has in place a process to set objectives and that the chosen objectives support and align with the entity's mission and are consistent with its risk appetite. Objective setting and company background in conjunction with an understanding of the internal environment provides perspective on the business so that the risk identification process can begin. Objective setting includes the strategic and business objectives and the relationship of each of these to the company's overall vision and mission.

- Identification and description of risks - internal and external events affecting achievement of an entity's objectives must be identified, distinguishing between risks and opportunities. Opportunities are channelled back to management's strategy or objective-setting processes. It is important not to limit this process to financial factors, i.e. it is necessary to take into account strategic risk, business risk, operational risk, market risk, credit risk and other.

- Risk Assessment (prioritization) - risks are analyzed, considering likelihood and impact, as a basis for determining how they should be managed. Risks are assessed on an inherent and a residual basis.

- Risk Response - the management selects risk responses - avoiding, accepting, reducing, or sharing risk - developing a set of actions to align risks with the entity's risk tolerances and risk appetite.
- Control Activities - policies and procedures are established and implemented to help ensure the risk responses are effectively carried out.

- Information and Communication - relevant information on risk management process is identified, captured, and communicated in a form and timeframe that enable people to carry out their responsibilities. Effective communication also occurs in a broader sense, flowing down, across, and up the entity.

- Monitoring and review - the entirety of enterprise risk management is monitored and modifications made as necessary. Monitoring is accomplished through ongoing management activities, separate evaluations, or both. Implementing an effective risk monitoring process involves several components.

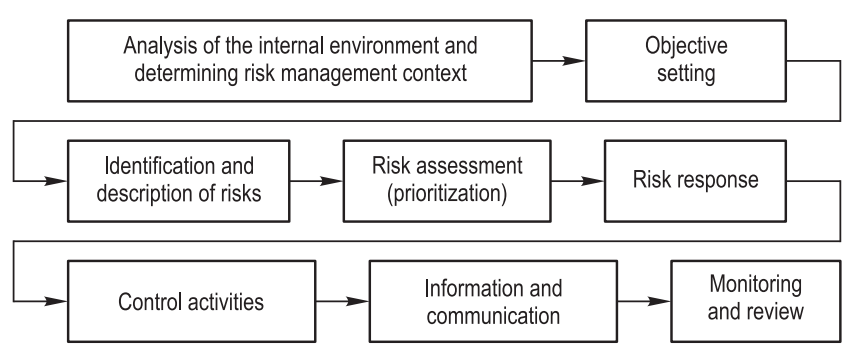

Fig. 6. Joint risk management framework [9]

In order for the internal audit to be efficient it must actively participate in risk management process, which must be based on joint risk management framework and evaluate this framework operational efficiency in the company, provide recommendations on its improvement.

Also internal audit is required not only to provide assurance on the efficiency of risk management system, but also to be involved in other value added activities, to participate in the improvement of the operations in the company. Such activities cannot hinder independence and objectivity of internal audit.

Still the question is whether there is a distinct line between assurance and consulting activities? Assurance activities certainly include the traditional internal audit, but also include other services. The glossary to the Standards [5] defines an assurance engagement as "an objective examination of evidence for the purpose of providing an independent assessment of risk management, control, or governance processes for the organization." Examples of the types of engagements that would be considered assurance engagements include financial, performance, compliance, system security, and due diligence audits. Consulting activities are defined as "advisory and client-related service activities, 
the nature and scope of which are agreed upon with the client and which are intended to add value and improve an organization's operations" [5]. This includes such activities as conducting internal control training, providing advice to management about the control concerns in new systems, drafting policies, and participating in quality teams. While this definition proved not to be sufficiently broad to extend to assurance services, it did capture several essential elements of the assurance activities. First, assurance engagements involve a systematic process of objectively obtaining and evaluating evidence for certain criteria. Second, these engagements require the existence of the established criteria. Third, the engagement involves the communication of the results to interested users, some third party apart from the provider of the service or those involved in the process or area under review. It is this third party that is the customer in the audit and assurance process, and who determines the value of the activity. As a result, the interest of this third party must be protected throughout the engagement in order for the engagement to be effective, which significantly complicates the process of providing auditing and assurance services.

Consulting, in contrast, involves only two parties, the auditor (service provider) and the activity management. The value added of the consulting engagement is determined by its value to activity management. There is no third party requiring protection, so there is no need for standards stating that the scope of work must be up to the auditor; in consulting services if the client (activity management) does not see the potential value of doing further work in an area the client is free to have the auditor stop. There may be written reports and auditors may do follow-up, but these are determined in the specific engagement contract and at the request, or at least with the agreement, of the client. Also consulting and assurance activities differ, as assurance engagements require an opinion as to the result, whereas consulting engagements produce recommendations if indeed there is any formal reporting involved. Additionally, assurance engagements are mandatory in the sense that the audit function cannot arbitrarily decide not to undertake an assurance engagement once it has been identified as an area of need [10]. Consulting engagements, on the other hand, may be declined by the audit function without need of reasons. The absence of staff skills or scheduling issues provides sufficient cause.

The most important aspect is that the assurance services are an obligation of the internal auditor and consulting activities are not obligatory, thus the internal auditors do such activities in order to add value to the organization and to be more competitive.

\section{$4^{\text {th }}$ area: Internal audit efficiency estimation}

According to the Standards on Internal Auditing it is obligatory to implement internal efficiency evaluation framework, based on which internal auditor should estimate whether its functions add value to the operations of the organization and whether recommendations are implemented properly, also it is recommended to quantify impact of internal audit on the operations of the company. Summary of internal audit efficiency estimation means is provided in Fig. 7 [11].

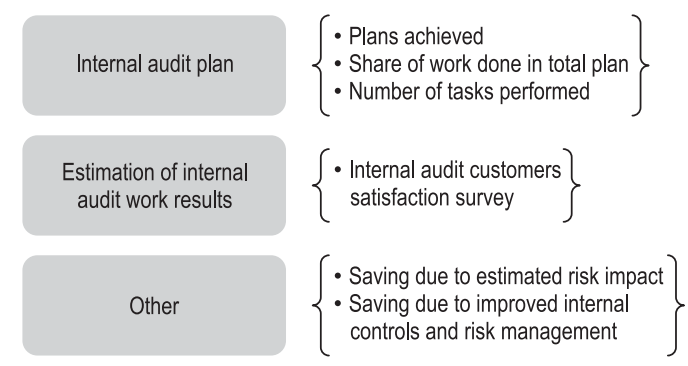

Fig. 7. Internal audit efficiency evaluation aspects

\section{Internal audit efficiency score (IAES)}

According to the above analysis taking into account the four main internal audit implementation areas Internal Audit Efficiency Score (IAES) was created. Table 2 indicates IAES calculation principles. Each of the four areas has maximum 25 score evaluations. Qualification area is divided into 3 sub-areas, i.e. certification -9 marks, experience -8 marks, professional improvement -8 marks. Internal audit strategy area is divided into 3 sub-areas, i.e. participation in risk management 11 marks, internal audit activity process -10 marks, other value added activity -4 marks.

Table 2. Internal Audit Efficiency Score calculation

\begin{tabular}{|l|c|}
\hline \multicolumn{1}{|c|}{ Area } & IAES \\
\hline 1. Subordination & Max. 25 \\
\hline Audit committee & 25 \\
\hline Supervisory board & 22 \\
\hline Management board (independent) & 22 \\
\hline Management board (dependent) & 18 \\
\hline General manager & 15 \\
\hline Chief financial officer & 10 \\
\hline 2. Qualification & Max. 25 \\
\hline Certification & Sub. max. 9 \\
\hline CIA & 9 \\
\hline
\end{tabular}


End of Table 2

\begin{tabular}{|c|c|}
\hline Area & IAES \\
\hline ACCA & 7 \\
\hline Lithuanian certified internal auditor & 5 \\
\hline Lithuanian certified auditor & 4 \\
\hline Experience & Sub. $\max .8$ \\
\hline Professional improvement & Sub. $\max .8$ \\
\hline Courses & 2 \\
\hline Internal training & 2 \\
\hline Newsletters & 2 \\
\hline Information databases & 2 \\
\hline 3. Internal audit strategy & Max. 25 \\
\hline Risk management & Sub. $\max .11$ \\
\hline Active participation & 11 \\
\hline Only assurance on risk management & 6 \\
\hline No participation & 0 \\
\hline Internal audit activity process & Sub. $\max .10$ \\
\hline Risk evaluation & 1 \\
\hline Analysis of business processes & 1 \\
\hline Data research & 1 \\
\hline $\begin{array}{l}\text { Internal control inspection and } \\
\text { evaluation }\end{array}$ & 1 \\
\hline Detailed audit tests & 1 \\
\hline Risk management & 1 \\
\hline Reporting & 1 \\
\hline Presentation of reports & 1 \\
\hline $\begin{array}{l}\text { Assistance implementing } \\
\text { recommendations }\end{array}$ & 1 \\
\hline Other consulting activities & 1 \\
\hline Other value added activities & Sub. max. 4 \\
\hline 4. Efficiency estimation & 25 \\
\hline Saving due to estimated risk impact & 4 \\
\hline $\begin{array}{l}\text { Saving due to improved internal } \\
\text { controls and risk managements }\end{array}$ & 4 \\
\hline $\begin{array}{l}\text { Internal audit customers satisfaction } \\
\text { survey }\end{array}$ & 6 \\
\hline Plans achieved & 6 \\
\hline Share of work done in total plan & 3 \\
\hline Number of tasks performed & 2 \\
\hline Total maximum IAES value & Max. 100 \\
\hline
\end{tabular}

Based on the value of IAES4 internal audit efficiency and development levels can be identified. These levels have the following characteristics:

\section{Subordination:}

$1^{\text {st }}$ level (score 10-18): Internal audit is not independent, as it is subordinated to functions, which it inspects and provides assurance on their activities, i.e. chief financial officer, general manager, dependent board.

$2^{\text {nd }}$ level (score 22): Internal audit is subordinated to independent board, the major part of the members in which are independent of the company management. Internal audit is independent.

$3^{\text {rd }}$ level (score 22-25): Internal audit is subordinated to independent audit committee or supervisory board and is independent.

$4^{\text {th }}$ level (score 25): Internal audit is subordinated to independent audit committee and is independent.

\section{Qualification:}

1st level (score 0-12): Chief internal auditor does not have any professional certificates, experience is various (no experience, or maximum required). No professional improvement process or it is the most efficient, however due to inefficiency on other areas internal audit cannot be efficient.

2nd level (score 13-21): Chief internal auditor has Lithuanian internal auditor or Lithuanian auditor certification, however these certifications do not correspond to the professional requirements for the internal auditor. Average experience level. No professional improvement process or it is the most efficient, however it is necessary and requires a lot of time to accumulate theoretical and practical knowledge on internal audit activities and efficiency assurance.

$3^{\text {rd }}$ level (score 21-23): International professional certificates are present, professional improvement is ensured within the requirements of these certificates. It is necessary to acquire more practical experience.

4th level (score 21-25): International professional certificates are present, average or highest practical experience, efficient professional improvement process, not only within the scope of certificate, but in various external trainings.

\section{Internal audit strategy:}

1st level (score 0-7): No participation in risk management process, no assurance on the efficiency of risk management system. Only detective activities are performed in order to determine already made mistakes and correct them, reporting is done and presented, however no feedback, recommendations are not implemented. 
2nd level (score 6-9): no participation in risk management process, no assurance on the efficiency of risk management system. Only detective activities are performed in order to determine already made mistakes and correct them, internal control system and its efficiency are evaluated, reporting is done and presented, recommendations on improvement of internal control system and its deficiencies are implemented. No other value added activities.

3rd level (score 15-19): Assurance on the efficiency of risk management system, participation in determining risks, however no assistance in creation and implementation of risk management means, they are only evaluated, recommendations are implemented, there is feedback, start of performing other value added activities. 4th level (score 22-25): Active participation in risk management process, risk identification, evaluation and selection of management means and their implementation. Preventive activities are performed, strategy corresponds to the described above risk-based internal audit, continuous feedback is ensured. Value added activities not hindering independence performed (i.e. fraud investigation, consulting activities, other).

\section{Efficiency estimation:}

1 st level (score 0-5): Not performed.

2nd level (score 2-11): Not performed.

3rd level (score 6-17): Start of efficiency estimation activities, comparisons of internal audit tasks with plan, plan completion is evaluated.

4th level (score 17-25): Continuous efficiency estimation, besides what is indicated under $3^{\text {rd }}$ level, in addition, internal audit customers satisfaction surveys are done. Also savings (decrease in costs, increase in revenues, profitability improvement) due to improved risk management and internal controls might be estimated.

Total IAES scores based on the internal audit efficiency and development level are the following:

$1^{\text {st }}$ level: IAES $=10-42$.

$2^{\text {nd }}$ level: IAES $=43-63$.

$3^{\text {rd }}$ level: IAES $=64-84$.

$4^{\text {th }}$ level: IAES $=85-100$.

In January 2007 the research on 300 biggest Lithuanian companies (based on the turnover for 2006) was carried out. It was determined that only 42 companies out of $300(14 \%)$ have separate internal audit functions. The efficiency and development level of internal audit functions was researched applying IAES. As indicated in Fig. 8, based on 38 replies received, it is obvious that internal audit function in Lithuanian companies correspond to $1^{\text {st }}$ and $2^{\text {nd }}$ efficiency and development level, therefore it is very important to improve internal

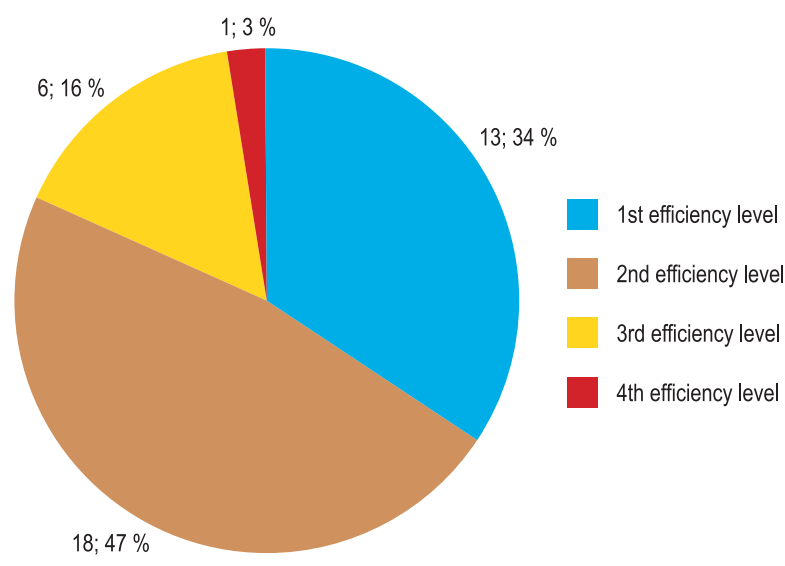

Fig. 8. Internal audit efficiency level in Lithuanian companies

audit functions to ensure they are independent and add value to the activities of companies.

IAES score is very useful when establishing internal audit function and ensuring its efficiency, and also estimating development level of existing internal audit function and taking improvement steps.

\section{Conclusions}

It is obvious that in the current business environment internal audit plays a very important role in the corporate governance, therefore it is required from the internal auditor not only to perform ordinary assurance activities, which were sufficient some time ago, but also to become a strategic partner of the organization and add value to its activities improving governance processes and ensuring their efficiency. Therefore internal audit function efficiency question becomes increasingly important. The evolution of the internal auditing activities also clearly emphasized that it is not enough for the internal auditor to perform pure assurance functions - in order to survive and be a part of the organization internal auditing must add value to the activities of the audited organization, however at the same time securing independence and objectivity.

There are no legal acts or other obligatory documents determining how internal audit must be organized and how its efficiency must be assured. Standards on Internal Auditing issued by the Institute of Internal Auditors are recognized by internal auditors and corporations all over the world, therefore they must be applied when implementing internal audit function or improving its activities. Analysis of the Standards allows specifying the four main areas for internal audit implementation and efficiency assurance, i.e. subordination, qualification, internal audit strategy and efficiency estimation. However, the Standards do not provide exact guidelines 
how to achieve best practice in these areas in order to have efficient internal audit function.

Therefore analysis of works performed by different researchers and practitioners and practical research of Lithuanian companies allow creating and applying in practice Internal Audit Efficiency Score (IAES), which determined 4 main internal audit efficiency levels and requires that internal audit corresponding to the highest $4^{\text {th }}$ efficiency level must be:

- subordinated to the independent audit committee. It is noticeable that research on governance structures in Lithuanian companies allows other subordination levels without damaging internal audit efficiency, however such recommendations must be strictly implemented;

- possess staff with highest professional qualification certificate - Certified Internal Auditor and extensive practical experience;

- be actively involved in risk management process, which must be based on the joint risk management framework, provide assurance on the risk management system efficiency, deliver improvement recommendations and ensure they are implemented, perform other value added activities without hindering independence and objectivity;

- create and implement internal efficiency estimation process, not only comparing internal audit tasks performed with plans, but obtaining feedback from parties using internal audit function results, and if possible quantify internal audit function results (i.e. decrease in costs, improvement in profitability).

IAES score is a practical means which can be used while implementing internal audit function or improving the existing one. Practical application of IAES was done analyzing 38 Lithuanian companies having internal audit function, estimating its efficiency and development level. The research indicated that the major part of these companies have internal audit function corresponding to the $1^{\text {st }}$ or $2^{\text {nd }}$ efficiency level (i.e. 13 and 18 companies accordingly). Therefore IAES score can be a very useful tool for Lithuanian companies improving their internal audit function efficiency or implementing internal audit in those companies, which still do not have it.

\section{References}

1. BOOKAL, L. Strengthening the internal auditor's role in the governance process. Altamonte Springs: The Institute of Internal Auditors, 2003. 34 p.

2. RAMAMOORTI, S. Internal auditing: history, evolution, and prospects. Altamonte Springs: The Institute of Internal Auditors, 2003. 24 p.

3. SAWYER, L. B.; DITTENHOFER, M. A. Sawyer's internal auditing: The practice of modern internal auditing 4th ed. Altamonte Springs: The Institute of Internal Auditors, 1996. 1446 p.

4. CHAPMAN, CH.; ANDERSON, U. Implementing the professional practices framework. Altamonte Springs: The Institute of Internal Auditors, 2002. 38 p.

5. Standards for the professional practice of internal auditing. Altamonte Springs: The Institute of Internal Auditors, $2002.32 \mathrm{p}$.

6. TAMOŠIŪNIENE, R.; SAVČUK, O. Internal auditing - assurance or consulting activity. In Conference material of the IVth international scientific conference on management and engineering. Sozopol (Bulgaria): June, 2006, p. 22-32.

7. AMADEUS Pan-European database with financial information on top 1.5 million European companies, 2006.

8. Internal audit benchmarking surveys 2002-2005, Great Britain, Russia, South Africa, New Zealand, Australia, Malaysia. London: Ernst \& Young, 2005. 32 p.

9. TAMOŠIŪNIENĖ, R.; SAVČUK, O. Risk management in organization - role of internal auditing. In Selected papers of the IVth International Scientific Conference Business and Management 2006. Vilnius: Technika, 2007, p.136-144.

10. ANDERSON, U. Assurance and consulting services. Institute of Internal Auditors Research Foundation, Altamonte Springs: The Institute of Internal Auditors, 2003. $34 \mathrm{p}$.

11. FRASER, J.; LINDSAY, H. 20 Questions directors should ask about internal audit. Toronto: Canadian Institute of Chartered Accountants, 2004. 28 p.

12. MCCAUL, L. Enhancing the value of internal audit - ten key questions. Accountancy Ireland, June 2006, 38 (3), p. 34-37. 